\title{
The sustainable project management: A review and future possibilities
}

\author{
V.K. Chawla ${ }^{a^{*}}$, A.K. Chanda ${ }^{b}$, S. Angra ${ }^{a}$ and G.R.Chawla ${ }^{c}$
}

${ }^{a}$ Department of Mechanical Engineering, National Institute of Technology, Kurukshetra, Haryana, India

${ }^{b}$ Department of Mechanical and Automation Engineering, G.B. Pant Engineering College, Delhi, India

${ }^{c}$ Consultant-Civil Engineering Department, North-Zone, Delhi Development Authority, Delhi, India

\section{H R O N I C L E}

Article history:

Received: July 5, 2017

Received in revised format: October 10,2017

Accepted: February 4, 2018

Available online:

February 4, 2018

Keywords:

Integrated framework

Literature review

Project management

Sustainable parameters

Sustainability

\section{A B S T R A C T}

\begin{abstract}
Sustainability in project operations such as financial, social and environmental sustainability is one of the most prominent issues of the present times to address. The increased focus on sustainable business operations has changed the viewpoint of researchers and corporate community towards the project management. Today sustainability in business operations along with sustainability of natural and environmental resources are of paramount significance which has further caused a huge impact on conception, planning, scheduling and execution of the project management activities. In this paper, a literature review between 1987 and 2018 on different issues affecting the sustainability in project management is carried out. The present study also identifies and discusses the future possibilities to apply computational procedures in order to estimate and optimize the sustainability issues in the management of projects, for example the computational evolutionary algorithms can be applied to formulate the multi-objective decisionmaking problem after considering critical factors of sustainability in the projects and then yielding optimized solutions for the formulated problem to achieve sustainability in the projects. A new integrated framework with the inclusion of feedback function for assessment of each decision and actions taken towards the sustainability of the projects is also identified and presented.
\end{abstract}

\section{Introduction}

In order to achieve long profitable business life in the light of the continuous developing uncertainties and scarcity of natural resources, there is an immediate need to consider and address sustainability issues in each and every field of the business. In the field of project management, the sustainability and the project management has been explored by a lot of researchers, separately. However, only a limited work is observed on finding modern ways for the assessment and application of sustainable project management. The sustainability ensures and integrates the financial, social and nature responsibility factors to harness the present resources judicially and also to offer the same for coming future generations around the globe (Kleindorfer et al., 2005; Gimenez et al., 2012). An attempt has been carried out to integrate sustainability and project management by few researchers namely Silvius et al. (2013,

* Corresponding author.

E-mail address: kumar6150046@nitkkr.ac.in (V.K. Chawla) 
2017), Gareis et al.(2013), Martens and Carvalho (2016a, 2016b), Sánchez (2015), Silvius (2013), Bernhardi et al. (2000), Bodea et al. (2010), Fernández and Rodríguez-López (2010), Hartig et al.(1996), Jones (2006), Raven et al. (2009), Turlea et al. (2010) and Vifell and Soneryd (2012). From the literature, a lot of research scope have been found for the development of the models, tools, methods, and techniques to integrate and gauge the sustainability and the project management (Singh et al., 2012; Thomson et al., 2011; John et al. 2016). The developed methods and models further can be extensively used by the companies for assuring the sustainability at the project level or at the organization level (Cole, 2005; Deakin et al., 2002). Pope et al. (2004) and Wilkins (2003) observed that all stakeholders of a project should decide their priorities after analyzing the effects of the project life-cycle under consideration on the throughout sustainability of the projects. Further, the evaluation of the sustainability should have some critical parameters to gauge the sustainability and can play a decisive and transparent role for all the stakeholders while taking significant decisions in the management of the projects (Mathur et al., 2008; El-Haram et al., 2007; Thomson et al., 2011). Singh et al. (2012), ElHaram et al. (2007) and Thomson et al. (2011) found that conceptual and technical issues for the sustainable project management are yet to be addressed. The green concepts including concepts of pollution reduction and continuous process improvements should be incorporated into sustainability assessment and evaluation tools (Gladwin et al., 1995).

In the present study, the literature on sustainability issues in project management from the year 19872018 has been reviewed and presented. The study is presented in five more sections. Section 2 describes the sustainability in projects, section 3 presents literature on selection of measures for the sustainable project management, the identified sustainable business policies from the literature are discussed in section 4 , section 5 presents the identified and possible future ways for sustainability into the projects and finally, the paper is concluded in section 6 .

\section{Sustainability in projects}

From the literature study, it is observed that most of the researchers considered sustainability in their works in a different perspective in terms of the triple bottom line approach. Some researchers consider sustainable or "green", construction projects, project management and largely present their works on the integration of financial factors and natural factors (Khodadadzadeh, 2016). However, research work presenting on development projects considers mainly the social factors (Silvius \& Schipper, 2014).

Some researchers also presented their works on the integration of sustainability in the project management on the basis of the triple bottom line approach and mentioned some sets of factors from a different perspective (Fernández-Sánchez \& Rodríguez-López, 2010; Bell \& Morse, 2003; Labuschagne \& Brent, 2006; Keeble et al., 2003). Aforesaid integration of financial, natural and social factors in project management does not present a holistic approach to sustainability for the project management. An empirical study for Brazilian industries on the basis of triple bottom line variables was performed by the Martens and Carvalho (2017). Authors observed that the suitability of triple bottom line approach is mainly related to the strategy and perspective of the project, which may differ from one project to another. Hence a gap is observed to fill for the development of universally accepted sustainability parameters which can be applied to the majority of projects to gauge and identify the possible sustainability in them.

Some parameters to incorporate sustainability in project management as identified by various researchers are mentioned below.

\subsection{Project lifecycle}

Many researchers discussed the orientation of sustainability in the field of the project management (Gareis et al., 2009, 2013; Labuschagne \& Brent, 2005, 2006; Eid, 2009; Silvius et al., 2012). The 
orientation of sustainability is linked to the project lifecycle and has some limitations towards the projects of short duration. The project lifecycle is always integrated with the product or deliverable which is developed from the project (Labuschagne \& Brent, 2006), so while finding the sustainability in project life cycle, the deliverable lifecycle and final product life cycle must also be considered (Labuschagne \& Brent, 2006). A general discussion on sustainable project management after consideration of project process, deliverables, and its effect was presented by the Silvius and Schipper (2014).

\subsection{Regional, National, and International Projects}

The location of the project is highly significant in determining its sustainability (Edum-Fotwe \& Price, 2009). Today the international economies are very sensitive towards the losses and gains, so it has become highly imperative to determine and assess the sustainability effects at regional, national and international level. To meet out the competition it is observed that companies are influenced by the various global policies, global partners, global stakeholders, global vendors and global customers etc. (Silvius \& Schipper, 2014). In projects, it can be linked to the global supply of products, materials or global application of resources into the projects located at different sites nationally or internationally (Cleland \& Gareis, 2006). Hence from the sustainability of projects point of view, it always becomes necessary to consider the level of the project i.e. whether the project is regional, national or global (Gareis et al., 2011).

\subsection{Ethicality in projects}

The project should be completed with consideration towards maintaining ethicality and social values in the project (Mishra et al., 2011). A number of researchers considered ethical and social values in their studies for sustainability in the project management (Schieg, 2009; Eskerod \& Huemann, 2013; Gareis et al., 2009, 2013). Project Management Association (2015), Project management Institute (2010) issued 'Codes of Ethics and Professional Conduct' which also emphasizes on consideration and inclusion of ethics and values in the projects. According to the project management institute code (2010) following values are mostly honored by the international project management fraternity: Fairness, Honesty, Responsibility, and Respect.

\subsection{Clear policies and procedures for the projects}

The clear policies and procedures for the projects in a company show that how openly a company formulates its policies, procedures, take decision and actions on various day to day issues. Further, it also implies how the policies and decisions of a company are going to affect environmentally and socially (ISO, 2010). It also indicates that the company is clear and liable towards its policies, procedures, actions, decisions and furthers their effect on company, stakeholders, nature, and society. The company will be held liable for its policies and procedures' effects (ISO, 2010). The clear policies of the company imply that the clear and relevant information to stakeholders, partners, and customers will be timely provided so that all stakeholders and customers can assess, evaluate the company actions and respond to any crucial issue, timely. The sustainability in project management can be incorporated by the companies with their clear policies, procedures, and liability towards them. For achieving sustainability into the project management companies should be open and proactive in the communication with all stakeholders and should also include effects on nature, society in short as well as in long-horizon (Silvius et al., 2012, Khalfan, 2006, Taylor, 2010). Present project management procedures allow project managers to give "only the required information" (Project Management Institute, 2013).

\subsection{Consideration for stakeholder's interest}

Stakeholder's involvement and participation in projects are significant from sustainability in projects point of view. The appropriate consideration for stakeholder's interest in projects supports in bilateral 
communication in the project management and further leads to overall stakeholder management (Silvius \& Schipper, 2014). The management should strive to involve, motivate and promote the stakeholder's participation in their projects. The stakeholder's participation must reflect the all project management procedures being performed (Silvius \& Schipper, 2014). Active stakeholder involvement is one of the basic pre-requisite for the sustainability of project management (ISO, 2010). Effective stakeholder's involvement requires a bilateral and open communication, development of common agenda among all stakeholders. The stakeholders as partners can identify the problematic area in the project and together can develop solutions to identified problems. The stakeholders can implement solutions and further gauge the progress of the projects (Goedknegt \& Silvius, 2012). A need to involve stakeholders in the decision-making process for sustainable project management was also identified by Eskerod and Huemann (2013).

\subsection{Managing uncertainty for sustainable projects}

The uncertainty is quite common in the project management. Some uncertain events or set of uncertain events can affect overall yield and objectives of any project (Office of the Government Commerce, 2010). To avoid uncertain events during the execution of the project, the uncertainty issues related to the project must be addressed, comprehensively. For example, financial uncertainty, uncertainty with respect to nature and its resources, social uncertainty and socio-economic uncertainty. The uncertainty issues should be identified and addressed appropriately to achieve sustainable project management (Winnall, 2013). For effective management of uncertainty, some preventive and precautionary procedures can be developed (Silvius, 2016a, 2016b). Due to uncertain, irreversible, typical, non-linear, dynamic and complex events in the projects, it is always recommended to prevent such uncertain developments and uncertain problems to happen in comparison to correcting or solving them later for the sustainability in the projects (Makui et al., 2010; Bakker et al., 2010). Most of the times the management of an organization is restricted to take certain steps in uncertainty and threats. The possibilities of project events, activities and their outcomes cannot be predicted (Kerzner, 2010). The uncertainty and risk in projects can have a huge impact on the overall accomplishment of project objectives. The uncertainty and risk in project management events can be judged through prior assessment of opportunity, threats in combination and their possible impact on the overall achievement of objectives. The uncertainty management and risk management are vital from sustainable project management point of view (Turner, 2016). Efficient and effective approaches and decisions for management of uncertainty and risk management assure accomplishment of sustainable project objectives. It also helps into a reduction of resource investment, maintaining standards in the projects etc.

\subsection{Implementing JIT-KANBAN for the waste elimination in the projects}

In order to have sufficient availability of resources, the elimination of waste is highly imperative in every process and activities (Khalfan, 2006; Maltzman \& Shirley, 2012; Ma, 2011). The elimination of waste is necessary for the sustainable project management. In the field of the project management sometimes the "waste" cannot be estimated. The Toyota Production System (a leading automobile manufacturer from Japan) introduced a novel JIT-KANBAN process, which only concentrates on the identification and total elimination of the waste from every production process and activity. Maltzman and Shirley (2013) identified the following types of wastes from the Toyota production system namely waiting, higher or lower inventory levels, excess production of goods, unnecessary transportation, over defects exceeding the tolerance values and inappropriate processing of goods. In the field of project management the waste in various processes and activities can be identified as unnecessary change in plans and requirements, excess and unutilized resources, high waiting or lead times, over and underestimation of resources, substandard processes, redundant processes, inferior quality of products, over communications i.e. over emails, communication gap, conclusion less meetings or meetings without any objective, etc. The relationship between the project scheduling, project planning, project 
execution and waste activities was identified by the Taylor (2010). The author tried to convey his findings with some examples.

The aforementioned waste activities can be eliminated at construction projects sites i.e. by performing off-site pre-fabrication of cemented blocks, welded iron bars, cement mixtures instead of doing fabrication on the construction site. This process frequently found to be used in construction projects for the development of highway in Delhi, India another example can be to create cement mixture into the cement carrying vehicle. In this process, the cement mixture is created inside the vehicle carrying and transferring the cement mixture at the construction sites. The rotating cement mixture making equipment is mounted at the rear of the vehicle and all the ingredients required for making appropriate cement mixture are kept inside the equipment and then the equipment is allowed to rotating while at the same time the vehicle starts moving towards the destination point of the construction site. The rotational speed of equipment is kept such that the cement mixture becomes ready when the vehicle reaches its destination point i.e. construction site. This has been widely used at the construction site of Delhi Metro, Delhi, India and also at the construction site of highway projects in Delhi, India. Use of these procedures allows a reduction in wastage of time and resources significantly and at the same time, right quantity and quality of resources reach at right time at the right place, which further satisfies the JIT and KANBAN procedures. The application of JIT and KANBAN procedures can also create opportunities for sustainability in the project management by having the less wastage, high quality, lesser price, appropriate utilization of the resources, application of the advanced technology and skills, overall uplift of the economy and many more advantages can be achieved. Further, the organizations managing projects must identify and learn from their previous mistakes mainly to minimize the wastage resources, materials, energy etc., (Eid, 2009; Silvius et al., 2012).

\subsection{Justified use of resources}

Sometimes companies to perform under competition try to overuse the natural, human and financial resources. This increase consumption of resources exponentially which further develops into threat and challenge towards the overall sustainability. Overwork pressures and tight deadlines create pressure on employees and labor working on the projects which may reflect in form of physical problems, tension, and mental agony (Van den Brink, 2013; Silvius et al., 2012). Similarly keeping infeasible and tight targets bound to create pressure on natural, financial and human resources and companies tries to exhaust them with a high rate which also results into wastage, depletion, dissatisfaction and finally causes losses to the society and nature. For sustainable profits and sustainable project management, the management of the organization must consider the justified use of resources in aforesaid aspects before setting up targets for any kind of projects.

\section{Selection of measures in sustainable project management.}

The sustainable project management can be achieved by taking appropriate measures towards it. Some procedure is identified from the literature namely stage-gate process (Kerzner, 2009), the iron triangle approaches (Papke-Shields et al., 2010), Atkinson (1999). Kerzner (2009) identified the stage-gate process as one of the core element in the project management. The conventional controlling procedures were found to be less effective in the management of projects. To overcome this, the stage gate process was developed. The stage gate process was found to promote, help and support in implementing the effective control measures. In the stage-gate, the gates represent the controlling decision points (Kerzner, 2009). The gates are applied to seek to go- ahead for the actions and also facilitate in early detection of losses into the projects so that resources can be judiciously utilized in the appropriate way. Another widely applied approach for appropriate selection of measures in project management is iron triangle (Papke-Shields et al., 2010; Atkinson, 1999). The iron-triangle represents triple constraint namely time, quality and cost. The stage gate approach also gauges a project success on time, quality, uncertainty, and cost parameters (Project Management Institute, 2013). 
The sustainability criteria must be considered while selecting the measures in the project management. The decisions in the context of projects must address sustainability at all stages of project planning, scheduling, execution, and completion furthermore the decision makers should consider benefits of customers, society, and the mother-nature (Zainul-Abidin, 2008; Habibi et al., 2018). Aaltonen and Kujala (2010) mentioned that the decision makers of projects must consider issues of environmentalists and social workers to achieve the success of their projects. Hwang and Ng (2013) studied main attributes for the decision making aspects of green construction projects. Authors observed decision making as the most critical and significant action to avoid and counter various potential threats and challenges of green construction projects. In order to take right decisions and selection of appropriate measures, the decision makers should improve and strengthen their information and skills in key fields and subjects to ensure successful and sustainable projects. It becomes clearly evident that the processes of selecting appropriate measures or consideration for right decision are highly significant for sustainable project management. Furthermore, it is also understood that the correct decision making is a unique attribute for any decision maker which should be constantly improved to achieve high efficiency and success rate in the actions taken for sustainable project management in the light of the taken decisions. From the literature review, a potential research gap for development, analysis, and application of evolutionary computing algorithms for taking optimum decisions on sustainable project management is also observed.

\section{Sustainable project business policies}

Achieving sustainability in project management is a significant task which also ensures value and benefits in overall operations. The sustainability can be commonly gauged by three basic factors namely environmental factor, financial factor and social factor. In the infrastructure projects, the sustainability of the product and its development process is highly significant in the light of their high impacts on environmental and social factors. The sustainable project management becomes more vital and crucial for infrastructure projects encountering changes to the society and indulging collaborators with different interests and expectations. Controlling the project ensures to achieve set targets of the project but for achieving sustainability in projects more versatile sustainability inclined project control practices should be considered, especially in control of infrastructure projects (Kivilä et al., 2017). The control over project execution phase for an infrastructure project is highly desirable for sustainability in project management. There should be an appropriate consideration for application of sustainability during the project execution, project control procedures and mutual agreement between the project stakeholders.

Nowadays the research has been more focused towards the sustainability as a target of the project and also adopted into the project management procedures (Gareis et al., 2013; Silvius \& Schipper, 2014). The researchers have analyzed and assessed sustainability-driven performance factors for the project management but a very less attention has been given to the development of project control procedures and practices to achieve throughout sustainability in the project targets particularly in the field of infrastructure delivery projects. From the literature, it is observed that there is a limited widely accepted interpretation for the sustainable project management or the sustainability in project management (Aarseth et al., 2017). Largely the research work on sustainability in project management is carried out on the basis of Brundtland Commission's interpretation of sustainable development which says that "development that meets the needs of the present without compromising the ability of future generations to meet their own needs", (World Commission on Environment and Development, 1987; Keeble, 1988; Butlin, 1989). Broadly speaking, the concept of sustainability can be classified into three main categories which are connected with each other and are equally significant from sustainable project operations and management point of view. The three categories are environmental sustainability, financial sustainability, and social sustainability. Earlier the main focus of project operations was to maintain high growth rate and high financial sustainability with least considerations on the environmental sustainability and social sustainability, but now it is globally accepted that the environmental sustainability, social sustainability and financial sustainability are equally significant for achieving the 
goal of sustainable project management (Elkington, 1994, 1997) also known as the triple-bottom-line approaches. Today the business leader's intentions are more inclined towards yielding broader business profits, ethics and the versatile values instead of only achieving their immediate project goals (Atkinson, 1999; Shenhar et al., 1997; Martinsuo \& Killen, 2014). The organizations should include sustainability into their project management practices and now should avoid considering only quality, cost and time factors (Silvius \& Schipper, 2014). The projects, especially infrastructure projects having a certain impact on natural resources and society, must include and evaluate the sustainability of the project and the sustainability of the delivery process holistically before execution of any infrastructure projects. The sustainability policies for the project management observed from the literature review is presented in Table1.

\section{Table 1}

Sustainability Policies in Project Management

\begin{tabular}{|c|c|c|c|}
\hline S. & Policies & Description & Researchers \\
\hline 1. & Sustainability Targets & $\begin{array}{l}\text { Objective considering sustainability aspects while } \\
\text { deciding project policies, with main consideration other } \\
\text { parallel aspects goes with the sustainability. }\end{array}$ & $\begin{array}{l}\text { Martens and Carvalho (2017), Verrier et al. (2014), } \\
\text { Herazo et al.(2012), Marcelino-Sadaba et al.(2015), } \\
\text { Ochoa (2014) }\end{array}$ \\
\hline 2. & $\begin{array}{l}\text { Sustainable } \\
\text { Vendor Development }\end{array}$ & $\begin{array}{l}\text { Training and development of vendors for incorporating } \\
\text { sustainable practices for example e.g. use of nature- } \\
\text { friendly materials. }\end{array}$ & $\begin{array}{l}\text { Ross et al.(2010), Jaillon and Poon (2008), Liu et al. } \\
\text { (2010), Eriksson et al.(2013) }\end{array}$ \\
\hline 3. & $\begin{array}{l}\text { Sustainability in Project } \\
\text { Planning Stage }\end{array}$ & $\begin{array}{l}\text { Involving sustainability aspects in project planning } \\
\text { stage. Considering sustainability quantifiers for the pro- } \\
\text { ject life-cycle. }\end{array}$ & $\begin{array}{l}\text { Sandoval et al. (2006), Wood et al.(2010), Marcelino- } \\
\text { Sadaba et al. (2015), Sanchez (2015), Zhong and Wu } \\
\text { (2015). }\end{array}$ \\
\hline 4. & $\begin{array}{l}\text { Considering Sustainable } \\
\text { Procedures }\end{array}$ & $\begin{array}{l}\text { Considering and promoting sustainable procedures in } \\
\text { view of law of land, regulations, and guidelines to sup- } \\
\text { port sustainability on the project level. }\end{array}$ & $\begin{array}{l}\text { Chen and Chambers, (1999), Bossink (2002), Ross et al. } \\
\text { (2010). }\end{array}$ \\
\hline 5. & $\begin{array}{l}\text { Supporting Sustainable } \\
\text { Project Practices }\end{array}$ & $\begin{array}{l}\text { Supporting and incorporating sustainability project } \\
\text { practices by the application of construction activities, } \\
\text { waste management activities etc. }\end{array}$ & $\begin{array}{l}\text { Bossink (2002), Jaillon and Chi- Sun (2010), Jaillon and } \\
\text { Poon (2008). }\end{array}$ \\
\hline 6. & $\begin{array}{l}\text { Indulging Sustainability } \\
\text { Promoting Elements }\end{array}$ & $\begin{array}{l}\text { The inclusion of sustainability promoting elements into } \\
\text { the project, which can initiate and maintain sustainabil- } \\
\text { ity at all level in a project. For example inclusion of local } \\
\text { and Govt. authorities, Social organizations, Cinema Art- } \\
\text { ists etc. }\end{array}$ & $\begin{array}{l}\text { Mathur et al. (2008), Lenferink et al. (2013), Ross et al. } \\
\text { (2010), Yunus and Yang (2014), Genus and Theobald } \\
\text { (2015), Johnson et al. (2006) }\end{array}$ \\
\hline 7. & $\begin{array}{l}\text { Incorporating Sustainability } \\
\text { Aptitude }\end{array}$ & $\begin{array}{l}\text { Training and development of project managers. Devel- } \\
\text { oping an inclination towards the sustainability and an } \\
\text { aptitude for sustainability in projects. Enhancing } \\
\text { aptitude of Govt. authorities and the general public also. }\end{array}$ & $\begin{array}{l}\text { Hwang and Ng (2013), Marcelino - Sadaba et al.(2015), } \\
\text { Martens and Carvalho (2017), Tabassi et al.(2016), Sa- } \\
\text { datrasool et al. (2016), Chen and Chambers (1999), Vez- } \\
\text { zoli (2003). }\end{array}$ \\
\hline
\end{tabular}

\section{Sustainability in future}

\subsection{Critical parameters}

The sustainability of the infrastructure projects is vital for shareholders expectations. In the infrastructure projects, fulfillment of shareholders and customers' expectations while executing the projects must be required for sustainability in projects. The inclusion of sustainability in projects can be carried out by various methods (Aarseth et al., 2017; Orouji, 2016). The total value of project including innovations in the project are described only in the early planning phase of the project (Kolltveit \& Grønhaug, 2004; Klakegg, 2009). In general, the companies take decisions about sustainability without complete knowledge of critical decision factors and later while executing the project the companies update their information and revise their decisions for material selection, development procedures and an estimate of resources is required for the completion of projects (Kolltveit \& Grønhaug, 2004; Wu \& Pagell, 2011). 


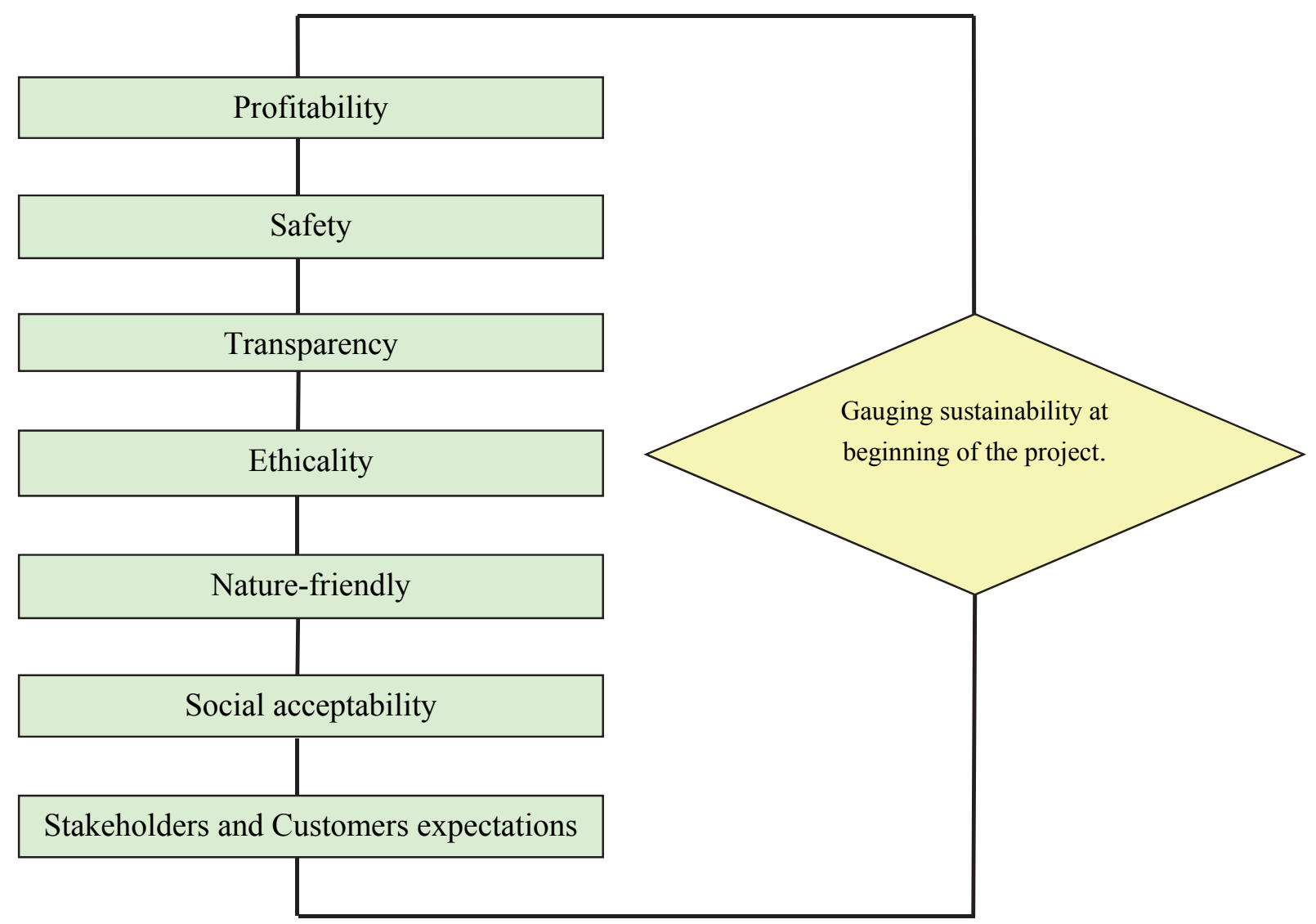

Fig. 1. Critical parameters to gauge sustainability in the projects

The sustainable project management for its complete life cycle (Fig. 2) can be gauged at the initial stage accurately on seven critical parameters namely:
1. Profitability
2. Safety
3. Transparency
4. Ethicality

5. Nature-friendly

6. Social acceptability

7. Fulfilling stakeholders and the customer's expectations.

Companies can ensure sustainability in their projects by formulating multi-objective project criteria by considering aforesaid critical parameters and convert the multi-objective project criteria into the single objective one by application of appropriate weights according to the weighted sum approach. Further, the investigations can be carried out by computational simulation and optimization of the formulated objective functions by application of nature-inspired evolutionary algorithms or Design of Experiments. For example Modified Memetic Particle Swarm Optimization, Grey Wolf Optimization Algorithm, Simulated Annealing Algorithm and Genetic Algorithm etc. (Chawla et al., 2018a, 2018b, 2018c; Hartmann, 1998, Pich et al., 2002; Sadjadi et al., 2009; Sadjadi \& Sadi-Nezhad, 2017; Moghadam et al., 2012; Sadi-Nezhad, 2017; Hafezalkotob, 2018; Hashemi et al., 2018). The evaluation of sustainable project management should not be limited to only planning and design stage. The project execution and the project delivery should also be considered for holistic evaluation and comparison of sustainability for the whole project management life-cycle. This can provide a new horizon for research in the field of integrated sustainable project management in which evaluation of sustainability in projects are not only limited to planning and design stage but also includes the project execution, the project schedule, the project control, and the project delivery stages. Bebbington et al. (2007), Singh et al. (2012) and Hardi (1997), observed gaps in models, procedures, tools to measure the sustainability of project management. Further authors also pointed out the need for systematic monitoring, measuring, 
and understanding of critical sustainability parameters so as to have the development in sustainability. Labuschagne et al. (2005) observed a void in procedures available for quantifying sustainability in operations. Brent and Petrick (2007) and Heuberger et al. (2007) analyzed the effect on the environment in light of Kyoto protocol and the project life cycles.

\subsection{Integrated framework}

The sustainable project management highly depends on decision makers, policy makers and implementation of decisions and policies towards sustainability in the projects. The decisions on company policies as well as their implementation both are carried out by the company's human resources. There are generally three main levels of human resources in any project company. The three levels are, the project staff (the lowest level includes staff, supervisor and junior managers), the project manager (the middle level of management includes manager, senior manager, general manager), and the management of project company (High level of management, policymakers include directors, chief executive officer, vice president, and the president) also shown in Fig. 2. For the smooth business operations and management, there must be appropriate coordination, connection and appropriate delegation of power and responsibilities in between the aforesaid three levels of human resources and should be clearly between all. In order to achieve sustainability into projects, the feedback component should be added at each level of the project management organization and the feedback may be taken for each decision, action, and process and furthermore, the feedback should be assessed and reviewed judicially by the organization, stakeholders, and customers so as to take corrective action in view to achieve sustainability into the projects. The proposed integrated framework for sustainability into the projects is also portrayed in Fig. 2.

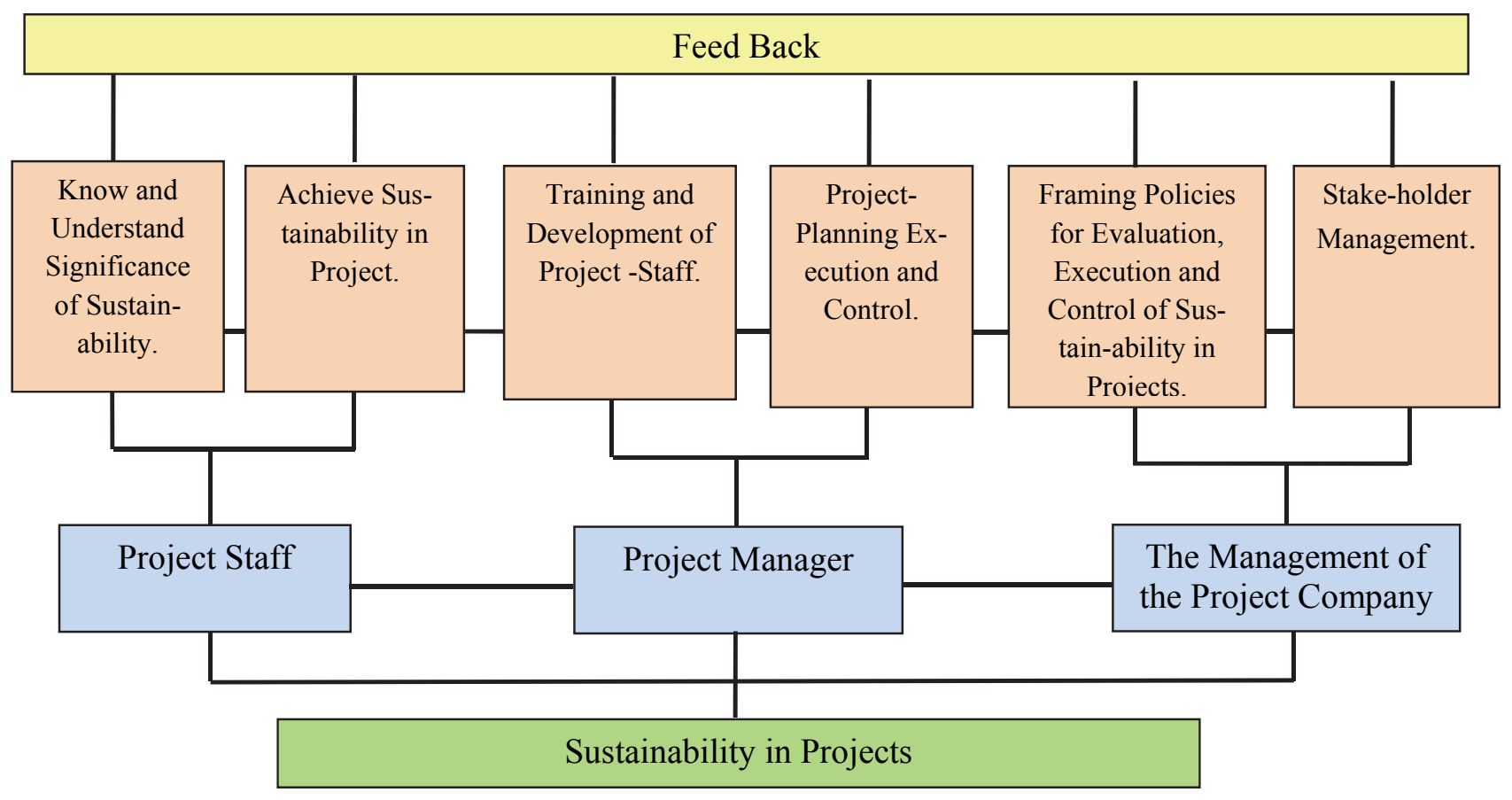

\section{Conclusion}

Fig. 2. Integrated framework for sustainability in projects

In the present study, a literature review on various issues on the sustainability aspect of the project management has been presented. The literature on the sustainable project management has been presented over the period 1987-2018 for simple understanding about challenges, threats, opportunities, procedures, and benefits of the sustainability in the field of project management. In the paper, various factors of sustainability as perceived by eminent researchers were identified and discussed along with the sustainable policies and process of selection of numerous measures to achieve sustainability into 
the projects. From the literature review, a possibility for a new horizon for research and analysis in the field of sustainable project management has been found as

i) Extensive computational procedures and evolutionary algorithms can be applied in the field of sustainable project management so that optimum level of resources can be estimated and used accordingly.

ii) Some critical parameters from sustainable project management such as profitability, safety, transparency, ethicality, nature-friendly, social acceptability, fulfilling the stakeholders and the customer's expectations were also identified to use aforesaid parameters as the weighting parameters in the multi-objective sustainable project management problems to identify and gauge the sustainability issues for the projects under consideration.

iii) A new integrated framework for assessment and evaluation of sustainability in project management by inclusion and evaluation of feedback function, for each and every activity, decision and policy by the organization are also presented and discussed.

\section{References}

Aarseth, W., Ahola, T., Aaltonen, K., Økland, A., \& Andersen, B. (2017). Project sustainability strategies: A systematic literature review. International Journal of Project Management, 35(6), 10711083.

Atkinson, R. (1999). Project management: cost, time and quality, two best guesses and a phenomenon, its time to accept other success criteria. International journal of project management, 17(6), 337342.

Aaltonen, K., \& Kujala, J. (2010). A project lifecycle perspective on stakeholder influence strategies in global projects. Scandinavian Journal of Management, 26(4), 381-397.

Bebbington, J., Brown, J., \& Frame, B. (2007). Accounting technologies and sustainability assessment models. Ecological Economics, 61(2), 224-236.

Bernhardi, L., Beroggi, G. E., \& Moens, M. R. (2000). Sustainable water management through flexible method management. Water Resources Management, 14(6), 473-495.

Bodea, C. N., Elmas, C., Tănăsescu, A., \& Dascălu, M. (2010). An ontological-based model for competences in sustainable development projects: a case study for project's commercial activities. Amfiteatru economic, 27, 177-189.

Bossink, B. A. (2002). A Dutch public-private strategy for innovation in sustainable construction. Construction Management \& Economics, 20(7), 633-642.

Brent, A. C., \& Petrick, W. (2007). Environmental impact assessment during project execution phases: towards a stage-gate project management model for the raw materials processing industry of the energy sector. Impact Assessment and Project Appraisal, 25(2), 111-122.

Butlin, J. (1989). Our common future. By World commission on environment and development.(London, Oxford University Press, 1987, pp. $383 £ ~ 5.95$.).

Chawla, V., Chanda, A., \& Angra, S. (2018a). Scheduling of multi-load AGVs in FMS by modified memetic particle swarm optimization algorithm. Journal of Project Management, 3(1), 39-54.

Chawla, V., Chanda, A., \& Angra, S. (2018b). Automatic guided vehicles fleet size optimization for flexible manufacturing system by grey wolf optimization algorithm. Management Science Letters, 8(2), 79-90.

Kumar, V. Chawla, Chanda, A., \& Angra, S. (2018c). Evaluation of Hybrid Dispatching Rules for Simultaneous Scheduling of AGVs in FMS. 1st International Conference on New Frontiers in Engineering, Science \& Technology, New Delhi, India, January 8-12, 2018,105-112

Chen, J. J., \& Chambers, D. (1999). Sustainability and the impact of Chinese policy initiatives upon construction. Construction Management \& Economics, 17(5), 679-687.

Cole, R. J. (2005). Building environmental assessment methods: redefining intentions and roles. Building Research \& Information, 33(5), 455-467.

Deakin, M., Huovila, P., Rao, S., Sunikka, M., \& Vreeker, R. (2002). The assessment of sustainable urban development. Building Research \& Information, 30(2), 95-108. 
De Bakker, K., Boonstra, A., \& Wortmann, H. (2010). Does risk management contribute to IT project success? A meta-analysis of empirical evidence. International Journal of Project Management, 28(5), 493-503.

Eid, M. (2009). Sustainable development \& project management. Cologne: Lambert Academic Publishing, 176.

El-Haram, M., Walton, J., Horner, M., Hardcastle, C., Price, A., Bebbington, J., \& Atkin-Wright, T. (2007, June). Development of an integrated sustainability assessment toolkit. In Conference proceedings, International Conference on Whole life Urban Sustainability and its Assessment.

Elkington, J. (1994). Towards the sustainable corporation: Win-win-win business strategies for sustainable development. California management review, 36(2), 90-100.

Elkington, J. (1997). Cannibals with forks. The triple bottom line of 21st century, 73.

Eriksson, P. E., Olander, S., Szentes, H., \& Widén, K. (2014). Managing short-term efficiency and long-term development through industrialized construction. Construction management and Economics, 32(1-2), 97-108.

Eskerod, P., \& Huemann, M. (2013). Sustainable development and project stakeholder management: What standards say. International Journal of Managing Projects in Business, 6(1), 36-50.

Fernández-Sánchez, G., \& Rodríguez-López, F. (2010). A methodology to identify sustainability indicators in construction project management-Application to infrastructure projects in Spain. Ecological Indicators, 10(6), 1193-1201.

Gareis, R., Huemann, M., Martinuzzi, A., Weninger, C., \& Sedlacko, M. (2013, April). Project management and sustainable development principles. Project Management Institute.

Genus, A., \& Theobald, K. (2015). Roles for university researchers in urban sustainability initiatives: the UK Newcastle Low Carbon Neighbourhoods project. Journal of Cleaner Production, 106, 119126.

Gimenez, C., Sierra, V., \& Rodon, J. (2012). Sustainable operations: Their impact on the triple bottom line. International Journal of Production Economics, 140(1), 149-159.

Gladwin, T. N., Kennelly, J. J., \& Krause, T. S. (1995). Shifting paradigms for sustainable development: Implications for management theory and research. Academy of management Review, 20(4), 874-907.

Goedknegt, D., \& Silvius, A. J. G. (2012). The implementation of sustainability principles in project management. In Proceedings of the 26th IPMA World Congress (pp. 875-882).

Habibi, F., Barzinpour, F., \& Sadjadi, S. (2018). Resource-constrained project scheduling problem: review of past and recent developments. Journal of Project Management, 3(2), 55-88.

Hafezalkotob, A. (2018). A fuzzy leader-follower game approach to interaction of project client and multiple contractors in time/cost trade-off problem. Journal of Project Management, 3(2), 105 120.

Hardi, P. Z. (1997). Assessing sustainable development (No. C024. 003). The International institute for Sustainable Development.

Hartmann, S. (1998). A competitive genetic algorithm for resource-constrained project scheduling. $\mathrm{Na}$ val Research Logistics (NRL), 45(7), 733-750.

Hartig, P. D., Hartig, J. H., Lesh, D. R., Lowrie, D. G., \& Wever, G. H. (1996). Practical application of sustainable development in decision-making processes in the Great Lakes Basin. International Journal of Sustainable Development \& World Ecology, 3(1), 31-46

Herazo, B., Lizarralde, G., \& Paquin, R. (2012). Sustainable development in the building sector: A Canadian case study on the alignment of strategic and tactical management. Project Management Journal, 43(2), 84-100.

Hashemi, P., Yazdanparast, R., Ghavamifar, A., \& Azadeh, A. (2018). An adaptive algorithm for performance assessment of construction project management with respect to resilience engineering and job security. Journal of Project Management, 3(1), 23-38.

Heuberger, R., Brent, A., Santos, L., Sutter, C., \& Imboden, D. (2007). CDM projects under the Kyoto Protocol: A methodology for sustainability assessment-experiences from South Africa and Uruguay. Environment, Development and Sustainability, 9(1), 33-48. 
Hwang, B. G., \& Ng, W. J. (2013). Project management knowledge and skills for green construction: Overcoming challenges. International Journal of Project Management, 31(2), 272-284.

International Organization for Standardization (2010). ISO 26000. Guidance on Social Responsibility, Geneva.

Jaillon, L., \& Poon, C. S. (2010). Design issues of using prefabrication in Hong Kong building construction. Construction Management and Economics, 28(10), 1025-1042.

Jaillon, L., \& Poon, C. S. (2008). Sustainable construction aspects of using prefabrication in dense urban environment: a Hong Kong case study. Construction Management and Economics, 26(9), 953-966.

John, B., Kadadevaramath, R., \& Edinbarough, I. (2016). Application of multistage process control methodology for software quality management. Journal of Project Management, 1(2), 55-66.

Johnson, C., Lizarralde, G., \& Davidson, C. H. (2006). A systems view of temporary housing projects in post-disaster reconstruction. Construction Management and Economics, 24(4), 367-378.

Jonny Klakegg, O. (2009). Pursuing relevance and sustainability: Improvement strategies for major public projects. International Journal of managing projects in business, 2(4), 499-518.

Keeble, B. R. (1988). The Brundtland report:'Our common future'. Medicine and War, 4(1), 17-25.

Kerzner, H. (2010). Project management best practices: achieving global excellence (Vol. 14). John Wiley \& Sons.

Khodadadzadeh, T. (2016). Green building project management: obstacles and solutions for sustainable development. Journal of Project Management, 1(1), 21-26.

Khalfan, M. M. (2006). Managing sustainability within construction projects. Journal of Environmental Assessment Policy and Management, 8(01), 41-60.

Kivilä, J., Martinsuo, M., \& Vuorinen, L. (2017). Sustainable project management through project control in infrastructure projects. International Journal of Project Management, 35(6), 1167-1183.

Klakegg, O. J., Williams, T., \& Magnussen, O. M. (2009, August). Governance frameworks for public project development and estimation. Project Management Institute.

Kleindorfer, P. R., Singhal, K., \& Wassenhove, L. N. (2005). Sustainable operations management. Production and Operations Management, 14(4), 482-492.

Kolltveit, B. J., \& Grønhaug, K. (2004). The importance of the early phase: the case of construction and building projects. International Journal of Project Management, 22(7), 545-551.

Labuschagne, C., Brent, A. C., \& Van Erck, R. P. (2005). Assessing the sustainability performances of industries. Journal of cleaner production, 13(4), 373-385.

Lenferink, S., Tillema, T., \& Arts, J. (2013). Towards sustainable infrastructure development through integrated contracts: Experiences with inclusiveness in Dutch infrastructure projects. International Journal of Project Management, 31(4), 615-627.

Liu, C., Zhang, K., \& Zhang, J. (2010). Sustainable utilization of regional water resources: experiences from the Hai Hua ecological industry pilot zone (HHEIPZ) project in China. Journal of Cleaner Production, 18(5), 447-453.

Ma, U. (2011). No waste: managing sustainability in construction. Gower Publishing, Ltd.

Makui, A., Mojtahedi, S. M., \& Mousavi, S. M. (2010). Project risk identification and analysis based on group decision-making methodology in a fuzzy environment. International Journal of Management Science and Engineering Management, 5(2), 108-118.

Maltzman, R., \& Shirley, D. (2012). Green project management. CRC Press.

Maltzman, R., \& Shirley, D. (2013). Project Manager as a Pivot Point for Implementing Sustainability in an Enterprise. Sustainability Integration for Effective Project Management, 262-278.

Marcelino-Sádaba, S., González-Jaen, L. F., \& Pérez-Ezcurdia, A. (2015). Using project management as a way to sustainability. From a comprehensive review of a framework definition. Journal of cleaner production, 99, 1-16.

Martens, M. L., \& Carvalho, M. M. (2016 a). The challenge of introducing sustainability into project management function: multiple-case studies. Journal of Cleaner Production, 117, 29-40. 
Martens, M. L., \& Carvalho, M. M. (2017). Key factors of sustainability in project management context: A survey exploring the project managers' perspective. International Journal of Project Management, 35(6), 1084-1102.

Martinsuo, M., \& Killen, C. P. (2014). Value management in project portfolios: Identifying and assessing strategic value. Project Management Journal, 45(5), 56-70.

Mathur, V. N., Price, A. D., \& Austin, S. (2008). Conceptualizing stakeholder engagement in the context of sustainability and its assessment. Construction Management and Economics, 26(6), 601-609.

Moghaddam, B. F., Ruiz, R., \& Sadjadi, S. J. (2012). Vehicle routing problem with uncertain demands: An advanced particle swarm algorithm. Computers \& Industrial Engineering, 62(1), 306-317.

Ochoa, J. J. (2014). Reducing plan variations in delivering sustainable building projects. Journal of Cleaner Production, 85, 276-288.

Office of the Government Commerce (2010). Management of Risk: Guidance for Practitioners, Norwich.

Orouji, M. (2016). Critical success factors in project management. Journal of Project Management, $1(1), 35-40$

Papke-Shields, K. E., Beise, C., \& Quan, J. (2010). Do project managers practice what they preach, and does it matter to project success?. International journal of project management, 28(7), 650-662.

Pich, M. T., Loch, C. H., \& Meyer, A. D. (2002). On uncertainty, ambiguity, and complexity in project management. Management science, 48(8), 1008-1023.

Pope, J., Annandale, D., \& Morrison-Saunders, A. (2004). Conceptualizing sustainability assessment. Environmental Impact Assessment Review, 24(6), 595-616.

Project Management Institute, 2013. A Guide to Project Management Body of Knowledge (PMBOK® Guide), fifth ed. Project Management Institute, Newtown Square, PA USA.

Raven, R. P., Jolivet, E., Mourik, R. M., \& Feenstra, Y. C. (2009). ESTEEM: Managing societal acceptance in new energy projects: A toolbox method for project managers. Technological Forecasting and Social Change, 76(7), 963-977.

Ross, N., Bowen, P. A., \& Lincoln, D. (2010). Sustainable housing for low-income communities: lessons for South Africa in local and other developing world cases. Construction Management and Economics, 28(5), 433-449.

Sadatrasool, M., Bozorgi-Amiri, A., \& Yousefi-Babadi, A. (2016). Project manager selection based on project manager competency model: PCA-MCDM Approach. Journal of Project Management, 1(1), 7-20.

Sadjadi, S. J., Jafari, M., \& Amini, T. (2009). A new mathematical modeling and a genetic algorithm search for milk run problem (an auto industry supply chain case study). The International Journal of Advanced Manufacturing Technology, 44(1-2), 194.

Sadi-Nezhad, S. (2017). A state-of-art survey on project selection using MCDM techniques. Journal of Project Management, 2(1), 1-10.

Sadjadi, S., \& Sadi-Nezhad, S. (2017). Ranking Canadian oil and gas projects using TOPSIS. Journal of Project Management, 2(3), 87-92.

Sánchez, M. A. (2015). Integrating sustainability issues into project management. Journal of Cleaner Production, 96, 319-330.

Sandoval, M. C., Veiga, M. M., Hinton, J., \& Sandner, S. (2006). Application of sustainable development concepts to an alluvial mineral extraction project in Lower Caroni River, Venezuela. Journal of Cleaner Production, 14(3), 415-426.

Shenhar, A. J., Dvir, D., \& Levy, O. (1997, July). Project success: a multidimensional, strategic concept. In Innovation in Technology Management-The Key to Global Leadership. PICMET'97: Portland International Conference on Management and Technology (p.391). IEEE.

Silvius, A.J.G., Schipper, R., Planko, J., van den Brink, J., \& Köhler, A. (2012). Sustainability in Project Management. Gower Publishing, Farnham.

Silvius, G. (Ed.). (2013). Sustainability integration for effective project management. IGI Global.

Silvius, A. J., \& Schipper, R. P. (2014). Sustainability in project management: A literature review and impact analysis. Social Business, 4(1), 63-96. 
Silvius, G. (2016 a). Integrating sustainability into project risk management. managing project risks for competitive advantage in changing business environments, 23-44.

Silvius, A. (2016 b). Sustainability as a competence of Project Managers. PM World J, 9, 1-13.

Silvius, A. G., Kampinga, M., Paniagua, S., \& Mooi, H. (2017). Considering sustainability in project management decision making; An investigation using Q-methodology. International Journal of Project Management, 35(6), 1133-1150.

Singh, R. K., Murty, H. R., Gupta, S. K., \& Dikshit, A. K. (2009). An overview of sustainability assessment methodologies. Ecological indicators, 9(2), 189-212.

Tabassi, A. A., Roufechaei, K. M., Ramli, M., Bakar, A. H. A., Ismail, R., \& Pakir, A. H. K. (2016). Leadership competences of sustainable construction project managers. Journal of Cleaner Production, 124, 339-349.

Taylor, T. (2010). Sustainability Interventions-for managers of projects and programmes. Centre for Education in the Built Environment.

Thomson, C. S., El-Haram, M. A., \& Emmanuel, R. (2011, June). Mapping sustainability assessment with the project life cycle. In Proceedings of the Institution of Civil Engineers-Engineering Sustainability (Vol. 164, No. 2, pp. 143-157). Thomas Telford Ltd.

Turlea, C., Roman, T. D., \& Constantinescu, D. G. (2010). The project management and the need for sustainable development. Metalurgia International, 15, 121-125.

Turner, R. (2016). Gower handbook of project management. Routledge.

Van den Brink, J. (2013). How Positive Psychology can Support Sustainable Project Management. Silvius. JG TharpJ.(Eds.), Sustainability Integration for Effective Project Management, 245-260.

Verrier, B., Rose, B., \& Caillaud, E. (2016). Lean and green strategy: the lean and green house and maturity deployment model. Journal of Cleaner Production, 116, 150-156.

Vezzoli, C. (2003). A new generation of designers: perspectives for education and training in the field of sustainable design. Experiences and projects at the Politecnico di Milano University. Journal of Cleaner Production, 11(1), 1-9.

Vifell, Å. C., \& Soneryd, L. (2012). Organizing matters: how 'the social dimension 'gets lost in sustainability projects. Sustainable Development, 20(1), 18-27.

Wilkins, H. (2003). The need for subjectivity in EIA: discourse as a tool for sustainable development. Environmental Impact Assessment Review, 23(4), 401-414.

Winnall, J. L. (2013). Social sustainability to social benefit: Creating positive outcomes through a social risk-based approach. In Sustainability Integration for Effective Project Management (pp. 95-105). IGI Global.

Wood, M. D. L., Mathieux, F., Brissaud, D., \& Evrard, D. (2010). Results of the first adapted design for sustainability project in a South Pacific small island developing state: Fiji. Journal of Cleaner Production, 18(18), 1775-1786.

World Commission on Environment and Development (1987). Our Common Future. Oxford University Press, Oxford.

Wu, Z., \& Pagell, M. (2011). Balancing priorities: Decision-making in sustainable supply chain management. Journal of Operations Management, 29(6), 577-590.

Yunus, R., \& Yang, J. (2014). Improving ecological performance of industrialized building systems in Malaysia. Construction Management and Economics, 32(1-2), 183-195.

Zainul-Abidin, N. (2008). Achieving sustainability through value management: A passing opportunity?. International Journal of Construction Management, 8(2), 79-91.

Zhong, Y., \& Wu, P. (2015). Economic sustainability, environmental sustainability and constructability indicators related to concrete-and steel-projects. Journal of Cleaner Production, 108, 748-756.

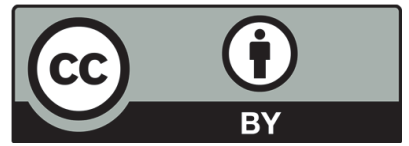

(C) 2018 by the authors; licensee Growing Science, Canada. This is an open access article distributed under the terms and conditions of the Creative Commons Attribution (CC-BY) license (http://creativecommons.org/licenses/by/4.0/). 